\title{
Effect of Extrusion Parameters on Textural Properties of Parboiled Rice based Bittergourd and Water Chestnut Blended Extrudates
}

\author{
Khanna Nidhi* and Singh Mohan \\ Department of Post Harvest Process and Food Engineering, College of Agricultural \\ Engineering, JNKVV, Jabalpur, 482004, Madhya Pradesh, India \\ *Corresponding author
}

\section{Keywords}

Extrusion cooking,

Processing

parameters,

Textural properties,

Bitter-gourd,

Parboiled rice,

Response surface

methodology

Article Info

Accepted:

15 June 2019

Available Online:

10 July 2019
Ready to eat extruded snacks were formulated by the flours of parboiled rice, bitter-gourd water chestnut and skim milk powder. The effects of extrusion processing parameters such as feed moisture (8-16\%, wb), blend ratio (3-15\%), barrel temperature $\left(120-200{ }^{\circ} \mathrm{C}\right)$, die head temperature $\left(160-240{ }^{\circ} \mathrm{C}\right)$ and screw speed (100-140 rpm) on the textural properties (i.e. crispness, hardness and cutting strength) of extruded snacks were investigated by response surface methodology using CCRD design. The values of crispness, hardness and cutting strength of extrudates were obtained ranged from 6 to 14 (No. of peaks), $0.761 \mathrm{~kg}$ to $1.952 \mathrm{~kg}$ and $0.852 \mathrm{~kg}$ to $1.978 \mathrm{~kg}$ respectively in this research study. The recommended optimum extrusion cooking conditions were found as feed moisture content (10.67 $\%)$, blend ratio of bitter-gourd: water chestnut (12:6), barrel temperature $\left(176^{\circ} \mathrm{C}\right)$, die head temperature $\left(180^{\circ} \mathrm{C}\right)$ and screw speed $(130 \mathrm{rpm})$.

\section{Introduction}

Food extrusion is a very efficient technology successfully adopted by snack food processing industries. Various types of food products different in shapes and sizes are manufactured by this versatile, handy and low cost cooking technology such as snacks, breakfast cereals, baby foods, texturized vegetable protein (TVP), pet foods, dried soups, snack foods, etc. (Toft,1979 and Verma, 2010). Better product quality and no process effluents are the major advantages of this technology (Harper and Clark, 1979; Camire et al., 1990).

The product acceptability to the consumers is highly dependent on texture of extruded snacks (Harper, 1981; Brncic et al., 2006). It is related with the response of the structure of food to applied forces and the physiological senses involved being vision, kinesthetic and hearing (Kanojia and Singh, 2016). Raw materials and feed moisture content are the important process parameters in extrusion cooking to obtain the desired product 
structure, texture, mouth feel, and many other characteristics of final products (Brncic et al., 2006). The desired textural properties (hardness, crispness, and cutting strength) of the product can be obtained by controlling the other operational process parameters such as extruder operating temperatures (barrel temperature and die head temperature), barrel pressure, feed rate and screw speed (Anton and Luciano, 2007; Kanojia and Singh, 2016). Feed moisture has a major contribution in thermo-mechanical liquefaction and gelatinization of starch (Filli et al., 2013). Air cells are formed due to superheated water vapour pressure. When the temperature of the extrudate is reduced below its glass transition temperature, it solidifies and maintains its expanded form. The shear and frictional force applied by the rotating screw and heating of the barrel, which turns the moistened starchy or proteinaceous food material into melting/plasticizing state. It transforms molecular structure and rheological properties of raw materials (Van Zuilichem, 1992 and Tiwari, 2011) resulted into porous, crispy and crunchy textured low density expanded final shaped product (Patil et al., 2005; Bhople and Singh, 2017).

The textural properties of foods can be estimated by different ways: (1) Sensory (subjective) evaluation is done by penal members using human sense organs and (2) Instrumentally (objective) evaluation in which it is done by using instruments like Texture Analyzer and Instron Compression Testing machine (Patil et al., 2005). Texture attributes are calculated from force-time or forcedisplacement data (Chen and Opara, 2013). Texture of food is related to the deformation, disintegration and flow of the food under a force. It is measured as the functions of mass, time and distance (Azam et al., 2016). Based on these facts, in this research study, the effects of extrusion parameters on the textural properties (i.e. crispness, hardness and cutting strength) of parboiled rice based bitter-gourd and water chestnut blended skim milk powder mixed extruded snacks were investigated.

\section{Materials and Methods}

\section{Materials used for preparation of extrudates}

Extrudates were prepared by using the raw materials namely parboiled rice, bitter gourds, water chestnut and skim milk powder and converted into flour by using hammer mill. These materials were procured from the local market of Krishi Upaj Mandi, Jabalpur. The proportions of raw materials were taken for the preparation of ready to eat extrudates as parboiled rice, $(80 \%)$ and skim milk powder (2\%) for each sample. Flours of bitter gourd and water chestnut were used in varying proportion i.e. 3 to $15 \%$. The blends in different proportion were made as per the experimental plan (Table 1).

\section{Formulation of extrudates}

Different blends of preconditioned raw materials were taken for the preparation of extrudates after moisture management. For this, initially moisture of the raw materials (flours of parboiled rice, bitter-gourd, water chestnut and skim milk powder) was estimated by AOAC (1980) method. Moisture management was done by addition or removal of water by drying as per the requirement. The extrudates were prepared by extrusion cooking process at $20 \mathrm{rpm}$ feeder screw speed into the Brabender single screw laboratory model extruder (D47055 DUISBURG, Germany) under different set of conditions mentioned in experimental design. Extrudates were prepared at constant parameters such as extrusion screw compression ratio: 3:1 and length-to-diameter ratio (20:1) with $3 \mathrm{~mm}$ round shape die. The temperature of feeding zone (barrel zone I) at $40^{\circ} \mathrm{C}$ and compression 
zone (barrel zone II) at $60^{\circ} \mathrm{C}$ was maintained constant while temperatures of mixing/cooking zone (barrel zone III) and die head section were varied as shown in Table 1 .

The expanded extruded products were cooled at room temperature and then packed in laminated poly-bags bags stored under moisture free conditions to test the textural properties of extrudates.

\section{Experimental design}

Here, five independent variables i.e. moisture content of feed (MC) blend ratio (BR), barrel temperature zone III (BT), die head temperature (DHT) and screw speed (SS) at five levels (Table 1) were taken as experimental design for this study. The influence of these variables on crispness, hardness and cutting strength were investigated by Response Surface Methodology (RSM) using second degree polynomial equations in Central Composite Rotatable Design (CCRD) of Design Expert software version 11.1.2.0 (30 days trial pack).

\section{Estimation of textural properties}

Textural properties (crispness, hardness and cutting strength) were estimated by TA. HD plus double column texture analyzer (Model: Stable Micro Systems). Different kinds of probes were used in this study such as cylindrical probe ( $3 \mathrm{~mm}$ stainless steel) and needle probe were used to determine hardness and crispness respectively and Warner Bratzler blade was used for cutting strength of extruded products.

Texture analyser is used to study the different textural parameters of food material by placing the test specimen into the test area and force is applied by different attachments such as probe, knife and fixture. The specimen is deformed as the force applied by attached probes. These tests were performed as per set parameters in the texture analyzer viz., Test option: Return to start, Pre - test speed: $5.0 \mathrm{~mm} / \mathrm{sec}$, Test speed: $2.0 \mathrm{~mm} / \mathrm{sec}$, Post test speed: $10 \mathrm{~mm} / \mathrm{sec}$, Distance moved: $5.0 \mathrm{~mm}$, Trigger force: $25 \mathrm{~g}$ and Trigger type: Auto. Force versus deformation data and plots are obtained by the Texture Analyzer. These plots are drawn automatically through the software of "Texture Exponent 32; Version 5.0.3.0" installed in PC.

\section{Results and Discussion}

\section{Crispness}

Crispness is associated with a low-density cellular structure that is brittle and generates a high-pitched noise when fractured (Le Meste et al., 2002). Crispness of extrudates analysed by observing the number of positive peaks on force-deformation curves (Kanojia and Singh, 2016; Stanley, 1986).

In this research study, the observed values of crispness of all extrudates was found in the range from 6 (No.) to 14 (No.) with respect to different combination of processing parameters. Maximum value of crispness (14 No.) was observed at moisture content (8 and $12 \%)$, blend ratio (9\%), barrel temperature $\left(160{ }^{\circ} \mathrm{C}\right)$, die head temperature $(160$ and 200 ${ }^{\circ} \mathrm{C}$ ) and screw speed (120 and $140 \mathrm{rpm}$ ).

Effect of all independent variables on responses were analysed by Response Surface Methodology (RSM) and second order quadratic equation of polynomial model. Relationship between independent variables and crispness of extrudates was adequately described by second order polynomial model in equation (1):

Crispness (No.) $=-49.21+3.71 \times \mathrm{MC}-1.91$ $\mathrm{x} \mathrm{BR}+0.67$ x BT $-0.14 \times \mathrm{DHT}+0.14 \times \mathrm{SS}-$ $0.02 \times$ MC $\times$ BR $-0.003 \times$ MC x BT $-0.01 \times$ 
MC x DHT $-5.41 \times 10^{-16} \times \mathrm{MC} \times \mathrm{SS}+0.01 \times$ $\mathrm{BR} \times \mathrm{BT}+0.002 \times \mathrm{BR} \times \mathrm{DHT}+0.004 \times \mathrm{BR}$ $x$ SS $-0.001 \times$ BT $\times$ DHT $-0.001 \times$ BT $\times$ SS + $1.04 \times 10^{-16} \times$ DHT x SS $-0.11 \times \mathrm{MC}^{2}-0.05$ $\mathrm{xBR}^{2}-0.001 \times \mathrm{BT}^{2}+0.001 \times \mathrm{DHT}^{2}+0.001$ $\mathrm{x} \mathrm{SS}^{2}$

The positive value of the coefficients of first order (linear terms; MC, BT and SS), interactive terms (BR and BT, BR and DHT, BR and SS and DHT and SS) and quadratic terms $\left(\mathrm{DHT}^{2}\right.$ and $\mathrm{SS}^{2}$ ) indicated that there was an increase in the response with the increasing level of parameters selected for this study and vice - versa.

Negative value of the coefficients for quadratic terms revealed that the maximum value of the response at the central point while positive coefficient showed the minimum response at the same points under this study.

The second order polynomial model showed a very strong association between different variables and the value of coefficient of determination i.e. $\mathrm{R}^{2}$ was found to be 0.83 and F- value of 2.78 for above second degree polynomial model. This model was significant $(\mathrm{p}<0.05 \%)$ having $\mathrm{p}$-value of 0.0424 . The response surface 3D graphs (Fig. 1 and 2) show the interactive effect of moisture of feed and barrel temperature; barrel temperature and screw speed on crispness of extrudates, respectively.

Figure 1 showed negative significant effect of moisture content on crispness of extrudates. That means it decreased with increase in feed moisture content. It may be due to reduced expansion and high bulk density of extrudates at higher feed moisture. Similar findings were also found by Kanojia and Singh (2016a) for okara enriched rice based extruded snacks. While crispness increased with increase in barrel temperature with respect to feed moisture. Because at higher temperature, transfer of water into the interior of starch molecules that helps for melting of starch granules rapidly which cause of porous texture resulted to increase in crispness of extrudates. Similar finding was also observed by Kanojia (2017).

In Figure 2 showed that crispness of extrudates increased with increase in barrel temperature as well as screw speed. It may be due to more shear and frictional force applied by rotating screw inside the barrel creates high pressure which improves mixing and homogeneous mass which help to increase the crispness of any finished product (Patil et al., 2005). And higher barrel temperature helps for melting of starch granules rapidly which cause of porous texture resulted to increase in crispness of extrudates.

From the above observations, it was found that feed moisture content, barrel temperature and screw speed play the major role in extrusion cooking to obtain the crispier finished product.

\section{Hardness}

It is expressed as the maximum force applied to compress the food. Minimum hardness of extrudates shows higher acceptability among the consumers. Hardness is the average force required for the probe to compress the final product.

The observed values of hardness of extrudates were found in the range from $0.761 \mathrm{~kg}$ to $1.952 \mathrm{~kg}$ with respect to different combination of processing parameters under this investigation. The minimum value $(0.761 \mathrm{~kg})$ of hardness of extrudates was obtained at moisture content $(8 \%)$, blend ratio $(9 \%)$, barrel temperature $\left(160{ }^{\circ} \mathrm{C}\right)$, die head temperature $\left(200{ }^{\circ} \mathrm{C}\right)$ and screw speed (120 rpm). 
The relationship between independent variables and hardness of extrudates was adequately described by second order quadratic equation of polynomial model in equation (2):

Hardness $(\mathrm{kg})=10.39-0.13 \mathrm{MC}-0.20 \times \mathrm{BR}$ $-0.05 \times$ BT $-0.06 \times$ DHT $+0.04 \times$ SS +0.004 $\mathrm{x} \mathrm{MC} \times \mathrm{BR}+0.0002 \times \mathrm{MC} \times \mathrm{BT}+9.45 \times 10$ ${ }^{05} \mathrm{x}$ MC $\mathrm{x}$ DHT $-0.002 \times \mathrm{MC} \times \mathrm{SS}-0.001 \mathrm{x}$ $\mathrm{BR} \times \mathrm{BT}+0.0004 \times \mathrm{BR} \times \mathrm{DHT}+0.001 \times \mathrm{BR}$ $\mathrm{x}$ SS $+0.0002 \times$ BT $x$ DHT $-9.70 \times 10^{-05} \mathrm{x}$ BT $x \mathrm{SS}+2.45 \times 10^{-05} \times$ DHT $\times \mathrm{SS}+0.02 \times$ $\mathrm{MC}^{2}+0.01 \times \mathrm{BR}^{2}+9.61 \times 10^{-05} \times \mathrm{BT}^{2}+4.89$ × $10^{-05} \times \mathrm{DHT}^{2}-8.82 \times 10^{-05} \times \mathrm{SS}^{2}$ Eq. (2)

The second order polynomial model showed a very strong association between different variables and the value of coefficient of determination i.e. $\mathrm{R}^{2}$ was found to be 0.92 and F- value of 6.06 for above second degree polynomial model for hardness. This model was significant $(\mathrm{p}<0.05 \%)$ having $\mathrm{p}$-value of 0.0019 . The response surface 3D graphs (Fig. 3 and 4) show the interactive effect of moisture of feed, blend ratio and screw speed on hardness of extrudates.

Figure 3 showed that hardness increased with increase in feed moisture content. Feed moisture showed the significant effect on hardness of extrudates. Similar findings were also observed by Lazou et al., (2011); Gat and Ananthanarayan (2015). Hardness increased with increase in blend ratio as shown in this figure. It may be due to high fibre content present in bitter-gourd. Similar findings of hardness of extrudates were also observed by Kanojia and Singh (2016b) for brown rice based safed musli enriched extrudates.

Figure 4 showed the interactive effect of moisture content and screw speed and revealed that hardness decreased with increase in screw speed for all levels of feed moisture content. Similar pattern also reported by Sharma et al., (2015). It may be due to high pressure and frictional force created by increased level of screw speed to modify the starch structure.

From the above observations, it was found that lower feed moisture content, lower level of blend ratio, higher screw speed and operating temperatures showed the great impact in extrusion cooking to obtain good result for hardness of extrudates.

\section{Cutting strength}

Cutting strength is same as the hardness but it is measured by different probe i.e. Warner Bratzler Blade to measure it by creating more surface area (Kanojia and Singh, 2016).

The observed values of cutting strength of extrudates were found in the range from 0.852 $\mathrm{kg}$ to $1.978 \mathrm{~kg}$ with respect to different combination of processing parameters under this investigation. Minimum value $(0.852 \mathrm{~kg})$ of cutting strength was observed at moisture content $(12 \%)$, blend ratio (9\%), barrel temperature $\left(160{ }^{\circ} \mathrm{C}\right)$, die head temperature $\left(200^{\circ} \mathrm{C}\right)$ and screw speed $(140 \mathrm{rpm})$.

The relationship between independent variables and cutting strength of extrudates was adequately described by second order quadratic equation of polynomial model in equation (3):

Cutting strength $(\mathrm{kg})=9.73-0.07 \times \mathrm{MC}-$ $0.24 \times$ BR $-0.04 \times$ BT $-0.06 \times$ DHT $+0.04 \times$ $\mathrm{SS}+0.004 \times \mathrm{MC} \times \mathrm{BR}+0.0002 \times \mathrm{MC} \times \mathrm{BT}-$ $0.0002 \times$ MC $\times$ DHT $-0.002 \times$ MC $\times$ SS $0.001 \times \mathrm{BR} \times \mathrm{BT}+0.0004 \times \mathrm{BR} \times \mathrm{DHT}+$ $0.001 \times \mathrm{BR} \times \mathrm{SS}+0.0002 \times \mathrm{BT} \times \mathrm{DHT}-8.84$ $\times 10^{-05} \times \mathrm{BT} \times \mathrm{SS}+2.34 \times 10^{-05} \times$ DHT $\times \mathrm{SS}+$ $0.02 \times \mathrm{MC}^{2}+0.01 \times \mathrm{BR}^{2}+6.90 \times 10^{-05} \times \mathrm{BT}^{2}$ $+5.71 \times 10^{-05} \times \mathrm{DHT}^{2}-0.0001 \times \mathrm{SS}^{2}$

Eq. (3) 
The second order polynomial model showed a very strong association between different variables and the value of coefficient of determination i.e. $\mathrm{R}^{2}$ was found to be 0.92 and F- value of 6.53 for above second degree polynomial model for hardness. This model was significant $(\mathrm{p}<0.05 \%)$ having $\mathrm{p}$-value of 0.0014 . The response surface 3D graphs (Fig. 5 and 6) show the interactive effect of moisture of feed and barrel temperature; blend ratio and die head temperature on cutting strength of extrudates, respectively.
Figure 5 showed that cutting strength of extrudates increased with increase in feed moisture content. It may be due to higher range of hardness obtained as increased in moisture content. Same trend was also found by Garg and Singh (2010). It decreased with increase in barrel temperature as shown in this figure. Because, as increased in temperature help to evaporate moisture frequently and more porous texture obtained which cause to reduce in cutting strength.

Table.1 Independent variables and their levels

\begin{tabular}{|c|c|c|c|c|c|c|c|}
\hline S.No & Variable Parameters & Code & \multicolumn{5}{|c|}{ Code levels } \\
\cline { 4 - 8 } & $\mathbf{1}$ & & $\mathbf{- 2}$ & $\mathbf{- 1}$ & $\mathbf{0}$ & $\mathbf{1}$ & $\mathbf{2}$ \\
\hline $\mathbf{2}$ & $\begin{array}{c}\text { Moisture content of } \\
\text { feed }(w b, \%)\end{array}$ & MC & 8 & 10 & 12 & 14 & 16 \\
\hline $\mathbf{3}$ & $\begin{array}{c}\text { Blend Ratio } \\
(\text { BG:WCF) }\end{array}$ & BR & $3: 15$ & $6: 12$ & $9: 9$ & $12: 6$ & $15: 3$ \\
\hline $\mathbf{4}$ & $\begin{array}{c}\text { Barrel Temperature } \\
\left(\text { Zone III }{ }^{0} \mathrm{C}\right)\end{array}$ & BT & 120 & 140 & 160 & 180 & 200 \\
\hline $\mathbf{5}$ & $\begin{array}{c}\text { Die head temperature } \\
\left({ }^{0} \mathrm{C}\right)\end{array}$ & DHT & 160 & 180 & 200 & 220 & 240 \\
\hline & $\begin{array}{c}\text { Screw Speed } \\
(\mathrm{rpm})\end{array}$ & SS & 100 & 110 & 120 & 130 & 140 \\
\hline
\end{tabular}

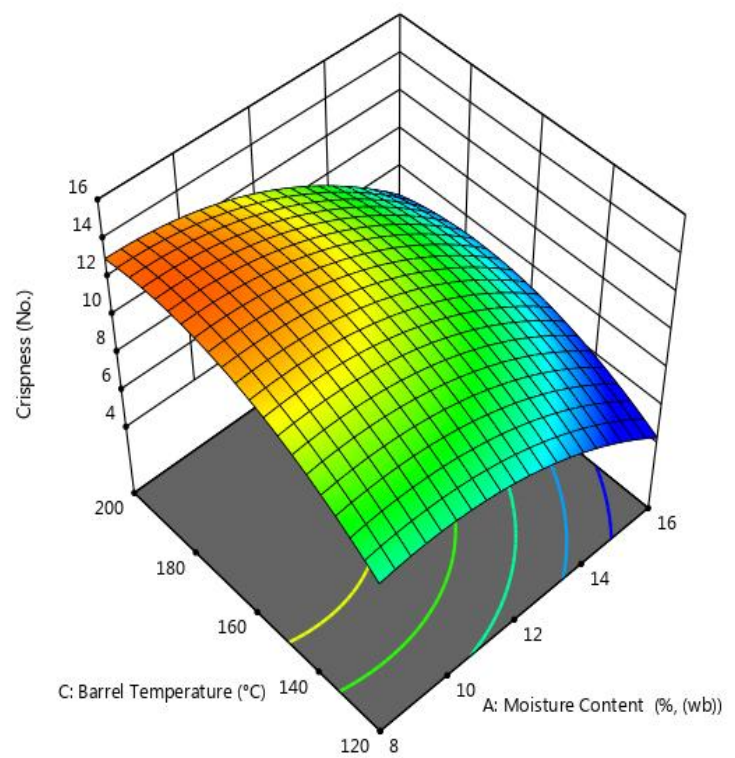

Fig.1 Effect of moisture content and barrel temperature on crispness of extrudates

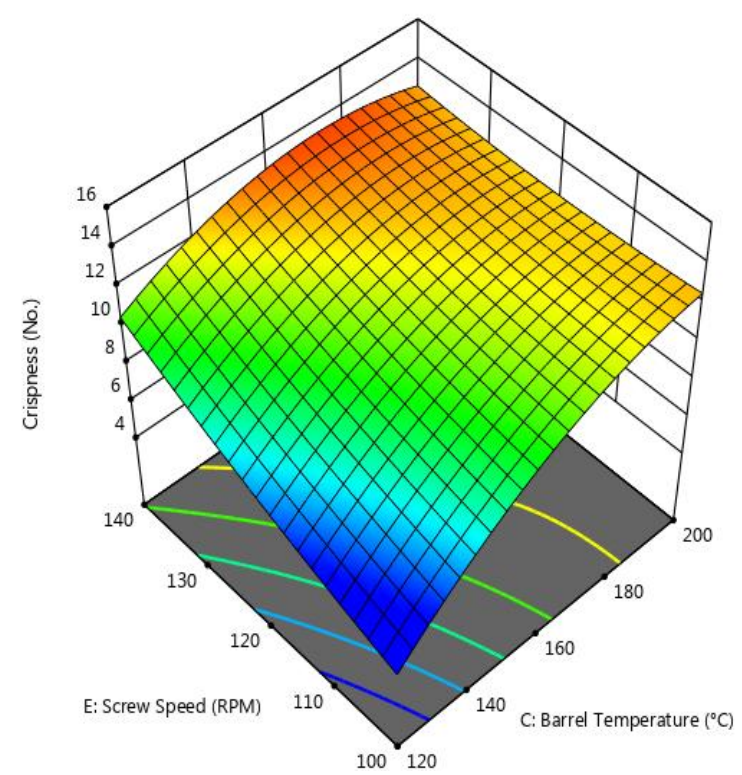

Fig.2 Effect of barrel temperature and screw speed on crispness of extrudates 


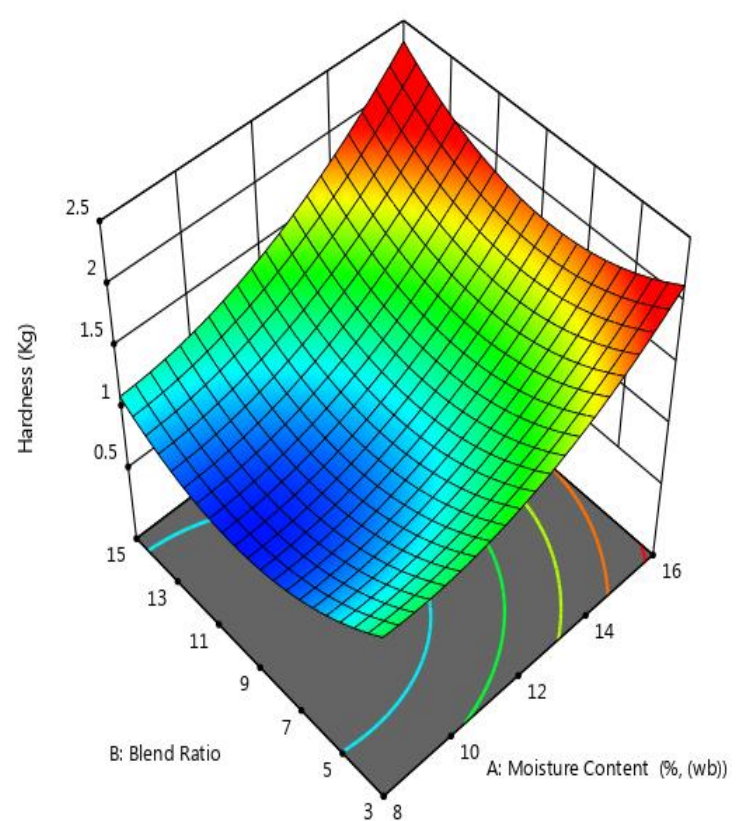

Fig.3 Effect of moisture content and blend ratio on hardness of extrudates

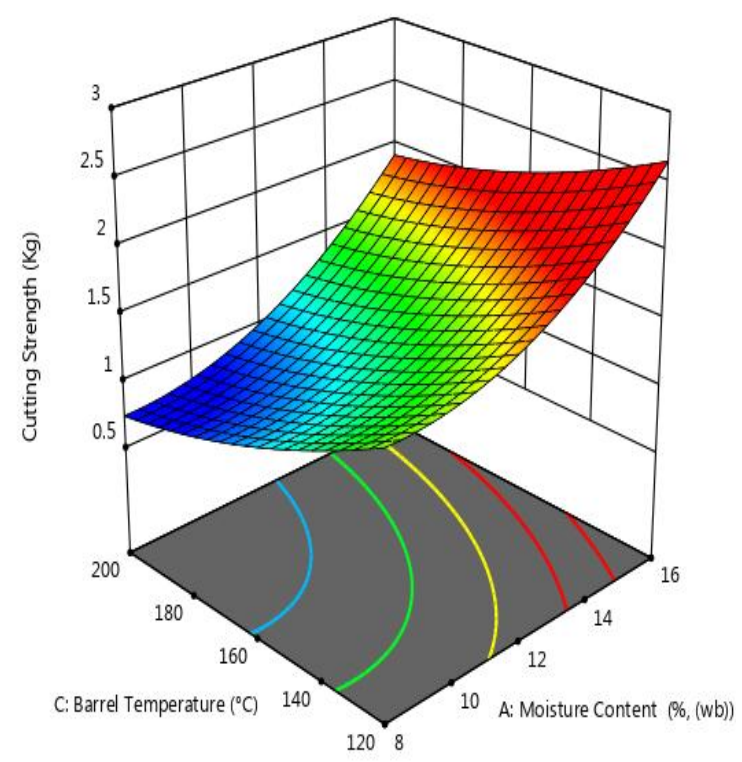

Fig.5Effect of moisture content and barrel temperature cutting strength of extrudates

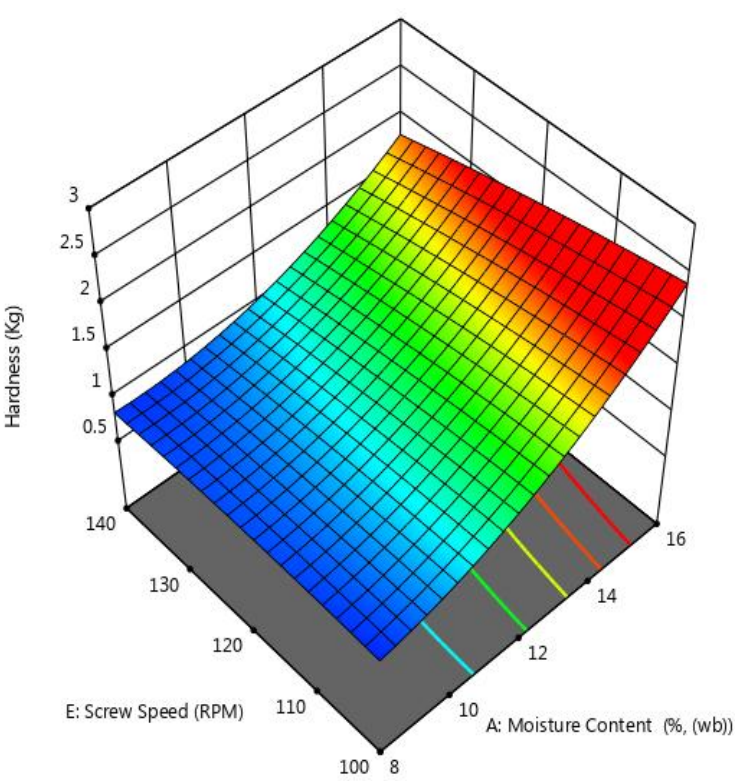

Fig.4 Effect of moisture content and screw speed on hardness of extrudates

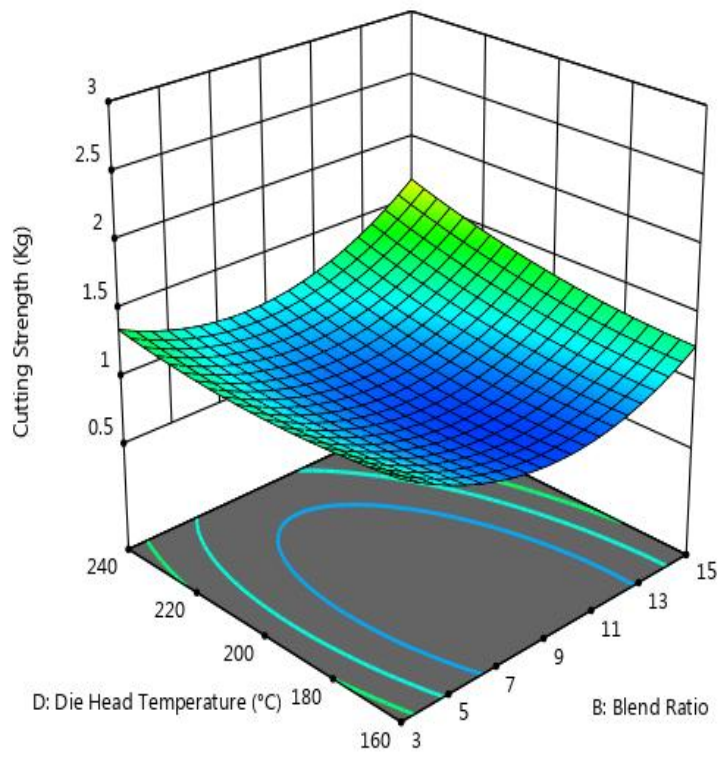

Fig.6 Effect of blend ratio and die head temperature on cutting strength of extrudates
Figure 6 depicted that cutting strength increased with increase in die head temperature as well as blend ratio (proportion of bitter-gourd flour in feed materials). It may be due to increase in fibre content present in bitter-gourd. The strengthening of fibre occurred in outer layer of extrudates as the die head temperature increased.

From the above observations, it was found that all parameters such as lower level of feed moisture content, blend ratio, higher operating 
temperature and screw speed showed the considerable effect on cutting strength of extrudates. The maximum and minimum values of cutting strength of extrudates were $1.978 \mathrm{~kg}$ and $0.852 \mathrm{~kg}$ respectively.

In conclusion, the low cost, easily digestible, extruded snacks developed by the flours of parboiled rice, bitter-gourd, water chestnut with skim milk powder in different proportion. The effect of independent variables on the responses were observed by response surface graph using second degree polynomial equations in Response Surface Methodology (RSM) of Central Composite Rotatable Design in Design Expert software version 11.1.2.0 (30 days trial pack). The best textural properties (maximum crispness, minimum hardness and minimum cutting strength) were obtained at optimum extrusion cooking conditions i.e. feed moisture content $(10.67 \%)$, blend ratio of bitter-gourd : water chestnut $(12: 6)$, barrel temperature $\left(176^{\circ} \mathrm{C}\right)$, die head temperature $\left(180{ }^{\circ} \mathrm{C}\right)$ and screw speed (130 rpm).

It was concluded that feed moisture showed the negative effect on crispness and positive effect on hardness and cutting strength. Barrel temperature revealed the positive effect on crispness and negative effect on cutting strength. Crispness increased with increase in screw speed while hardness decreased with it. Hardness and cutting strength both increased with increase in the proportion of bitter-gourd as high fibre content. Die head temperature showed the positive effect on cutting strength of extrudates.

\section{Acknowledgement}

The authors would like extend gratitude to Jawaharlal Nehru Krishi Vishva Vidhyalay (JNKVV), Jabalpur, M.P., for providing facilities and equipment for this study.

\section{References}

Anton A.A. and Luciano F.B. 2007. Instrumental Texture Evaluation of Extruded Snack Foods: A Review. Cienc. Tecnol. Aliment 5(4): 245-251.

AOAC.1980. Official methods of analysis, 13th edition, Association of Official Analytical Chemists, Washington, DC.

Azam M., Singh M. and Verma D.K. 2016. Textural Properties of Kodo (Paspalum scrobiculatum L.) based Soy Fortified Ready to Eat Extruded Snacks using Response Surface Methodology, Indian Journal of Science and Technology 9(4): 1-6.

Bhople S. and Singh M. 2017. Extrusion cooking technology for iron enriched foods: A Review. International Journal of Agriculture Sciences 9 (24): 4278-4281.

Brncic M, Tripalo B, Jezek D, Semenski D, Drvar N and Ukrainczyk M. 2006. Effect of twin-screw extrusion parameters on mechanical hardness of direct expanded extrudates, Article in Sadhana 31(5): 527-536.

Camire, M.E., Caminre, A. and Krumhar K. 1990. Chemical and nutritional changes in foods during extrusion. Critical Reviews in Food Science and Nutrition 29 (1): 35-57.

Chen L. and Opara U.L. 2013.Texture measurement approaches in fresh and processed foods- A review, Food Research International 51 (2): 823-835.

Filli K.B., Nkama I. and Jideani V.A. 2013. The effect of extrusion conditions on the physical and functional properties of millet - bambara groundnut based fura. American Journal of Food Science and Technology 1(4): 87-101.

Garg S.K. and Singh D.S. 2010. Optimization of extrusion conditions for defatted soyrice blend extrudates. Journal of Food Science and Technology 47(6): 606-612.

Gat Y and Ananthanarayan L. 2015. Effect of extrusion process parameters and pregelatinized rice flour on 
physicochemical properties of Ready-ToEat expanded snacks. Journal of Food Science and Technology 52(5): 26342645.

Harper J.M. and Clark J.P. 1979. Food Extrusion. Critical Reviews in Food Science and Nutrition, 11(2): 155-215.

Harper, JM. 1981. Extrusion of Foods, Vol. 1, CRC Press, Inc. Boca Raton, pp: 101-155.

Kanojia V. and Singh M. 2016. Extruded Product Quality Assessment Indices: A Review, Review article. International Journal of Agriculture Sciences 8(54): 2928-2934.

Kanojia V and Singh M. 2016a, Production of value added snacks from rice broken and okara by extrusion cooking technology. International Journal of Agriculture Sciences 8(51): 2321-2325.

Kanojia V and Singh M. 2016b. Assessment of Textural Properties of Brown Rice based Ready to Eat Extrudate Snacks Blended with Water Chestnut and Safed Musli Powder, Indian Journal of Science and Technology 9(38): 1-7.

Kanojia V. 2017. Process optimization for preparation of ready to eat extruded snacks from different blends of brown rice flour and water chestnut flour fortified with safed musli powder. $\mathrm{PhD}$ Thesis, JNKVV, Jabalpur.

Lazou A, Krokida M, Zogzas N, Karathanos V. 2011. Lentil-based snacks: Structural and textural evaluation, Procedia Food Science 1, 11th International Congress on Engineering and Food (ICEF11): 1593 1600.
Le Meste M., Champion D., Roudaut G., Blond G. and Simatos D. 2002. Glass transition and food technology: A critical appraisal. Journal of Food Science 67: 2444-2458.

Patil R.T., Berrios Jose De J, Tang J., Pan J. and Swanson B. 2005. Physical Characteristics of Food Extrudates -A Review, An ASAE Annual International Meeting; Paper No. 056166, Tampa Convention Center, Tampa, Florida.

Sharma M., Yadav D.N., Mridula D. and Gupta R.K. 2015. Protein enriched multigrain expanded snack: Optimization of extrusion variables. Proceedings of the National Academy of Sciences. India Section B: Biological Sciences 2015: 110.

Stanley D.W. 1986. Chemical and structural determinants of texture of fabricated foods. Food Technology 12: 65-76.

Tiwari V.K. 2011. Studies on blending whole brown rice for nutrient enrichment of rice based extrudates through Extrusion cooking technology. PhD Thesis, JNKVV, Jabalpur.

Toft G. 1979. Snack foods, continuous processing techniques. Cereal Foods World. 24: 142-143.

Van Zuilichem D.J. 1992. Extrusion Cooking. Craft or Science? Ph.D. Thesis, Wageningen University, Netherlands.

Verma D.K. 2010. Optimization of process parameters for development of protein enriched rice (Oriyza Sativa) based snack food through extrusion cooking. Ph.D. Thesis, JNKVV, Jabalpur.

\section{How to cite this article:}

Khanna Nidhi and Singh Mohan. 2019. Effect of Extrusion Parameters on Textural Properties of Parboiled Rice based Bittergourd and Water Chestnut Blended Extrudates. Int.J.Curr.Microbiol.App.Sci. 8(07): 2021-2029. doi: https://doi.org/10.20546/ijcmas.2019.807.242 